\title{
Phenotypic identification of indigenous fungi and lactic acid bacteria isolated from 'gatot' an Indonesian fermented food
}

\author{
ASTRIANI ASTRIANI ${ }^{1, v}$, NURUD DINIYAH ${ }^{3}$, JAY JAYUS $^{2,3}$, NURHAYATI NURHAYATI ${ }^{2,3, v v}$ \\ ${ }^{1}$ Graduate School of Biotechnology, Universitas Jember. Jl. Kalimantan No. 37, Kampus Tegalboto, Jember 68121, East Java, Indonesia. \\ `email: astri.unej@gmail.com \\ ${ }^{2}$ Center for Development of Advanced Sciences and Technology, Universitas Jember. Jl. Kalimantan No. 37, CDAST UNEJ, Jember 68121, East Java \\ Indonesia. \\ ${ }^{3}$ Department of Agricultural Products Technology, Faculty of Agricultural Technology, Universitas Jember. J1. Kalimantan No. 37, Kampus Tegalboto, \\ Jember 68121, East Java, Indonesia. Tel.: +62-331-321784. ^vemail: nurhayati.ftp@unej.ac.id
}

Manuscript received: 8 January 2018. Revision accepted: 30 April 2018.

\begin{abstract}
Astriani A, Diniyah N, Jayus J, Nurhayati N. 2018. Phenotypic identification of indigenous fungi and lactic acid bacteria isolated from 'gatot' an Indonesian fermented food. Biodiversitas 19: 947-954. As a traditional Indonesian food made from cassava, 'gatot' has special attracted characters of black appearance and chewy texture, mainly as a result of certain fungi and lactic acid bacteria $(\mathrm{LAB})$ during the spontaneous fermentation. However, many producers were failed to gain these typical properties since much unwanted microbial strain often appears during the spontaneous fermentation. Therefore, this study was conducted to isolate and identify the indigenous fungi and LAB which predominantly contributed in fermentation of cassava during 'gatot' production. Fungi and LAB were isolated from conventionally made of the 'gatot' followed by the phenotypic identification of the isolates based on the morphological and physiological properties. The fungi isolates were morphologically distinguished by the type of mycelia, the shape, and color of the sporangium, while the LAB strains were identified by the type of cell and colony form. In addition, the physiological behavior of the LAB isolates was characterized by their typical growth temperature, its catalase activity and its fermentation profile using BBL crystal kit test. The predominant fungi isolates were identified as Botryodiplodia theobromae, Rhizopus oligosporus, Trichoderma sp. and Aspergillus niger. B. theobromae had greyish white to black color of mycelia when it mature. $R$. oligosporus had globose sporangium and blackish grey color of the mature mycelia. Trichoderma sp. had green color of the mature sporangium and mycelia. A. niger had yellow color of the mycelia and black color of sporangium. Meanwhile, the indigenous LAB was majority identified as Lactobacillus manihotivorans, Bacillus licheniformis, Brevibacillus brevis and Lactobacillus fermentum. Those bacteria were gram-positive, rods shape, catalase-negative and grew optimally at $37^{\circ} \mathrm{C}$. The LAB also arise frequently in many spontaneously fermented food. $B$. theobromae, $R$. oligosporus, L. manihotivorans, and $L$. fermentum were potential and non-pathogenic microbial, which can be used as a starter culture to produce 'gatot' under controlled fermentation process.
\end{abstract}

Keywords: Indigenous fungi, lactic acid bacteria, non-pathogenic microbe, phenotypic identification, traditional food

\section{INTRODUCTION}

Cassava is one of the Indonesian raw material local food that eaten by some people as the rice substitute. It is a source of carbohydrate. Cassava can be classified into two types, the sweet and the bitter cassava. The sweet cassava is Manihot utilissima containing low cyanide acid, while the bitter cassava is Manihot esculenta Crantz containing high cyanide acid and toxic to consumed (FAO 2003; Burns et al. 2012; Chikezie and Ojiako 2013). In traditional Indonesian society, sweet cassava can be directly processed into traditional Indonesian snack, i.e. 'cenil', 'lupis', 'getuk lindri', 'tapai' and 'growol' (Putri et al. 2012; Nurhayati et al. 2014). On the other hand, the bitter cassava needs to be pre-treated to reduce cyanide acid, for example drying, soaking, starch extraction and fermentation before consumed (Padmaja and Steinkraus 2009). Generally, bitter cassava is processed into dried cassava ('gaplek'), modified cassava flour (mocaf), cassava starch, and traditional Indonesian fermented food, i.e. 'gatot' and 'tiwul.' $\square$

Gatot is a traditional food especially processed and consumed by old people in Trenggalek District, East Java, and Gunung Kidul District, Yogyakarta, Central Java, Indonesia. It is made by two different processes, spontaneous solid-state fermentation and spontaneous submerged fermentation. During solid state fermentation, the fungi grow on cassava tuber and produce greyish or black color on the inside and outside of the tuber (Purwandari 2000; Yudiarti and Sugiharto 2016). The 'gatot' has unique characteristics, i.e. black color of tuber, chewy texture and special flavor than the other cassava food. The black color of tuber and the unique flavor are determined by penetration of the fungal hyphae on the substrate and a phenolic compound as metabolic from fungi activities, while the chewy texture is determined from hydrolyzed of starch (amylose) by lactic acid bacteria. These special (unique) characters can appeared after steaming the 'gatot' for 30 minutes.

Fungi grow spontaneously during the 'gatotan' fermentation. Budhiatti et al. (1995) had isolated indigenous fungi from cassava starch, i.e. Rhizopus oligosporus, Aspergillus niger and Mucor griseocyanus. In another research, Yudiarto and Sugiharto (2016) found fungi from the 'gatotan' made from Central Java Indonesia, 
i.e., Rhizopus oryzae and Acremonium charticola. A dominant fungus (Botryodiplodia theobromae Pat.) was isolated in 'gatotan' from several areas in East Java and Central Java. This fungus was able to change the cassava tuber into black color in the inside and outside (Purwandari 2000). Lactic acid bacteria (LAB) also grew on the carbohydrate sources during submerged fermentation. Some LAB were isolated from fermented food in some countries, such as L. fermentum from "burong isda" a local food processed in Filipina (Olympia et al. 1995), $L$. manihotivorans from cassava sour starch fermentation in Columbia (Guyot et al. 2000), L. plantarum and L. fermentum from various Nigerian traditional amylaceous fermented food (Sanni et al. 2002) and L. salivarus and $L$. fructivorans from spontaneous fermentation of unripe banana in Indonesia (Nurhayati et al. 2011).

Several unwanted microbial strains often appear during the spontaneous fermentation of the 'gatot'. During solid state-fermentation, the unwanted microbial strains caused rotten cassava, not able to form black color in the inside and outside of cassava tuber and possible to be toxic during long time fermentation of 'gatotan' (more than ten days). Different area has different microflora diversity. Therefore, the dominant microbes could grow differently in another area (region). This study aimed to isolate and identify the indigenous fungi and LAB during 'gatot' production in Trenggalek District, Indonesia.

\section{MATERIALS AND METHODS}

\section{Production of the 'gatot' by spontaneous fermentation}

The bitter cassava (Manihot esculenta Crantz) 'Gembluk' variety was used as a raw material for the 'gatot' production. 'Gembluk' is a local cassava variety from Trenggalek, East Java, Indonesia. Cassava root was harvested on the nine-month-old plants. The making of the 'gatot' was initiated by peeling the cassava, then washed and pre-dried by sun-drying. The cassava was placed in an open space (on the roof) for four days. The pre-drying of cassava is intended as a trigger to expose various microflora from the air. The semi-dried cassava was fermented by solid-state fermentation in sacks for five days at room temperature $\left(26 \pm 2^{\circ} \mathrm{C}\right)$ then it was dried by sundrying to stop the fungi activities. Thus the obtained result is called as the 'gatotan'.

The 'gatotan' presented the greyish or black color on the inside and outside of the cassava tuber. It soaked in the water with the ratio of 1:4 (v/v) for four days (96 hours). The soaking process of the 'gatotan' was called spontaneous submerged fermentation. During submerged fermentation, lactic acid bacteria grew and hydrolized the 'gatotan'. The LAB growth indicated by decreased $\mathrm{pH}$ of the water from 6.00 to 4.00 . The product from solid state and submerged fermentation is called 'gatot'.

\section{Isolation of indigenous fungi from the 'gatotan'. $\square$}

Fungi were isolated from spontaneous solid state fermentation of the 'gatotan'. One gram of greyish or black 'gatotan' was inoculated in a petri dish containing $15 \mathrm{ml}$ of the MEA medium (malt extract agar). Isolation of the dominant fungi was based on the different color of mycelia, and also the color and shape of the sporangium, conidia or pycnidia (Zulkifli et al. 2017). The dominant fungi were inoculated on petri dish containing the MEA medium by continuous scratches using inoculating loop (ose). Then it was incubated at $30^{\circ} \mathrm{C}$ for 5 days. This step was repeated for several times until it achieved pure fungal species.

\section{Isolation of indigenous lactic acid bacteria from the 'gatot'. $\square$}

Lactic acid bacteria (LAB) were isolated from submerged fermentation water. Each $500 \mu \mathrm{L}$ samples of soaking water from various fermentation time, 24 hours (A), 48 hours (B) and 72 hours (C) were inoculated on the MRSA medium (de Mann rogosa agar) containing $\mathrm{CaCO}_{3}$ $(3 \% \mathrm{w} / \mathrm{v})$. The $\mathrm{CaCO}_{3}$ caused clear zone around the colony indicating the colony as $\mathrm{LAB}$ after incubation at $37^{\circ} \mathrm{C}$ for 24 hours. Screening of the LAB was based on the largest area of the clear zone on each colony of the isolate (Nurhayati et al. 2011). Two LAB isolates were selected from each fermentation time and inoculated on the petridish containing the MRSA medium by quadrant scratches using inoculating loop. Then the isolates were incubated at $37^{\circ} \mathrm{C}$ for 24 hours. The colony of LAB was purified by repeating the inoculation step until a single or pure colony of the indigenous LAB was obtained.

\section{Phenotypic identification of dominant indigenous fungi and lactic acid bacteria (LAB)}

Phenotypic identification of fungi was observed by the macroscopic and microscopic observations. The macroscopic observation of fungi was the color of colony and sporangium. The microscopic observation of fungi was conducted by slide culture method (Kusnadi et al. 2008; Kumar et al. 2012). One ose of fungi mycelia was inoculated in one drop of MEA medium on a sterile object glass and covered with a cover glass. The isolate was incubated at $30^{\circ} \mathrm{C}$ for four days. The inoculum was observed microscopically under the binocular XSZ-107 microscope at 100x and 400x magnification.

The phenotypic of LAB were identified based on morphological and physiological observation. The morphological observation consisted of typical of the colony, cell form and gram staining (Ammor et al. 2005). The typical of LAB colony was observed by visual observation, while cell form and gram staining were observed under the binocular microscope at $1000 \mathrm{x}$ magnification. The physiological identification consisted of catalase activity test, temperature growth and fermentation profile using BBL crystal kit (BD BBL crystal ${ }^{\mathrm{TM}}$ : MIND software, USA) (Ammor et al. 2005; Becton 2010). The catalase activity test was carried out by dropped $100 \mu \mathrm{L}$ of $\mathrm{H}_{2} \mathrm{O}_{2} 3 \%$ (w/v) on LAB colony at sterile object glass. The growth temperature test was done by inoculated $0.1 \mathrm{ml}$ of the $\mathrm{LAB}$ on $5 \mathrm{ml} \mathrm{MRSB}$ medium and incubated at $10^{\circ} \mathrm{C}$, $37^{\circ} \mathrm{C}$ and $50^{\circ} \mathrm{C}$ for 48 hours. Clouded appearance on the MRSB medium indicated that the LAB was growing.

The fermentation profile of LAB isolates was observed using BBL crystal positive gram kit test. Five oses of LAB 
isolate were suspended on $2.3 \mathrm{ml} \mathrm{BBL}$ crystal physiological buffer solution. The bacteria suspension was poured in a microtube plate of BBL crystal kit until the suspension filled the holes track on the microtube plate. Then it was closed with a cover plate containing 30 kinds of substrates. The plate of BBL crystal test was sealed by wet wipes to keep it moist and incubated at $37^{\circ} \mathrm{C}$ for 48 hours. The change of color and fluorescent on the holes of microtube plate indicated that the isolates fermented the substrate. Furthermore, the data from the color change and fluorescent were processed using software BBL Crystal kit (BD BBL Crystal ${ }^{\mathrm{TM}}$ : MIND software).

\section{RESULTS AND DISCUSSION}

\section{Fermented dried cassava ('gatotan')}

The spontaneous solid-state fermentation of the cassava produced various performance of the 'gatotan': black (Figure 1.A), patchy grayish black (Figure 1.B), and white appearance in the inside and outside of cassava tuber (Figure 1.C). Indonesian local society called a white 'gatotan' as a 'gaplek' (dried cassava). The different colors of the 'gatotan' are mainly affected by the different microflora activities on the substrate. During the solid state fermentation in a sack, various fungi were able to change the cassava tuber into greyish and black color appearance. Rhizopus oryzae, Acremonium charticola and B. theobromae Pat. were reported as the indigenous fungi which caused color changes of the cassava from white tuber into greyish and black in the inside and outside (Yudiarti and Sugiharto 2016; Purwandari 2000). The fungi produced a secondary metabolite that probably gave a specific flavor. The specific flavor on the 'gatotan' was caused by the phenolic compound. Purwandari et al. (2014) revealed that 'gatotan' flour fermented by $B$. theobromae had total phenolic compounds of $419.43 \mathrm{mg} / 100 \mathrm{~g}$. $\square$

The various species of microflora depend on the region, the sources of carbon (substrate), the water activity $\left(\mathrm{a}_{\mathrm{w}}\right)$ of raw material and the weather during fermentation. The various dominant fungi and $\mathrm{LAB}$ were found during fermentation at a different area such as Central Java
Indonesia, East Java Indonesia, Nigeria and Columbia (Buddhiati et al. 1995; Guyot et al. 2000; Purwandari 2000; Sanni et al. 2002; Yudiarti and Sugiharto 2016). During fermentation process, the carbon sources (substrates) also determined the growth of various species of microbial, i.e. species of Aspergilli on the grape pomade (a winery byproduct) (Senaye et al. 2015), some genus and species of amylolytic LAB on the starchy substrate (Reddy et al. 2008), and various species of fungi on the corn grain (Zulkifli and Zakaria 2017). In another case, the microbial activity reflected the changes in ecosystem properties between summer and winter at the Bohemian mountain, Central Europe (Zifcakova et al. 2016).

\section{Characteristic of contaminated 'gatotan' by unwanted microbial}

During fermentation process of the 'gatotan', some contaminant fungi as unwanted microbial grew dominantly than desired fungi (Figure 2). The contaminant fungi that grow predominantly during solid-state fermentation were Trichoderma sp. (Figure 2.A) and Aspergillus niger (Figure 2.B and 2.C). Instead of having black color, the unwanted fungi caused a different characteristic of the contaminated 'gatotan', such as unable to form black color on inside tuber and might result in a toxic on the cassava tuber. At certain times, the cassava could be rotten during solid-state fermentation (Figure 2.D). The rotten cassava was caused by the contamination of yeast. It made the cassava tuber become soft and smelled like acid and alcoholic aroma.

\section{The dominant indigenous fungi from 'gatotan' and its morphological characteristic}

The dominant indigenous microbe during 'gatotan' fermentation were fungi. Isolation and identification of indigenous fungi were based on the different color of mycelia and sporangium on morphological characterization. There were four isolates as the most dominant fungi in the 'gatotan'. The fungi isolates were coded as isolate 1, 2, 3, and 4 (Figure 3 ). The characterization of the dominant indigenous fungi was observed under the binocular XSZ107 microscope (Figure 4).

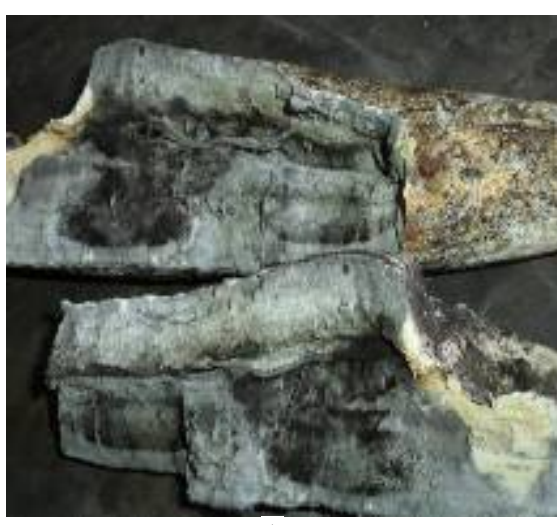

A

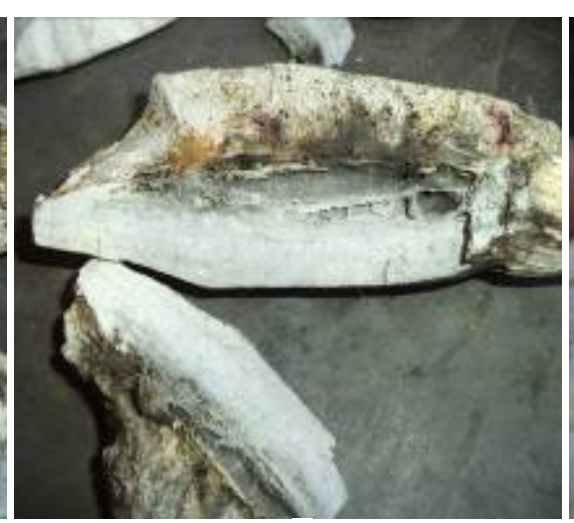

B

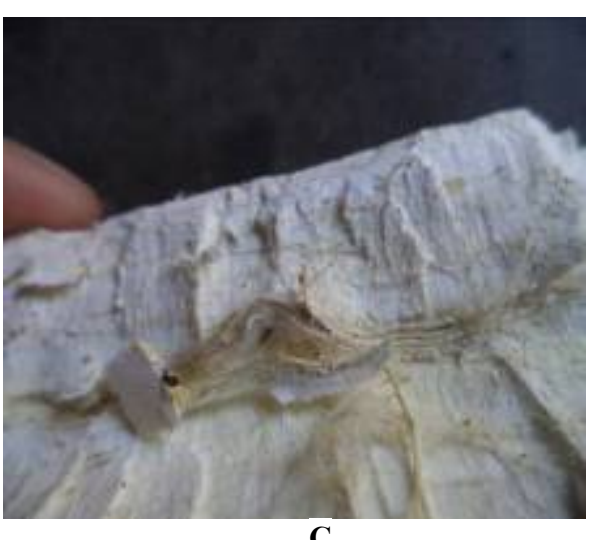

$\mathbf{C}$

Figure 1. Fermented dried cassava ('gatotan') with black (A), patchy grayish black (B) and white color appearance (C) in the tuber 


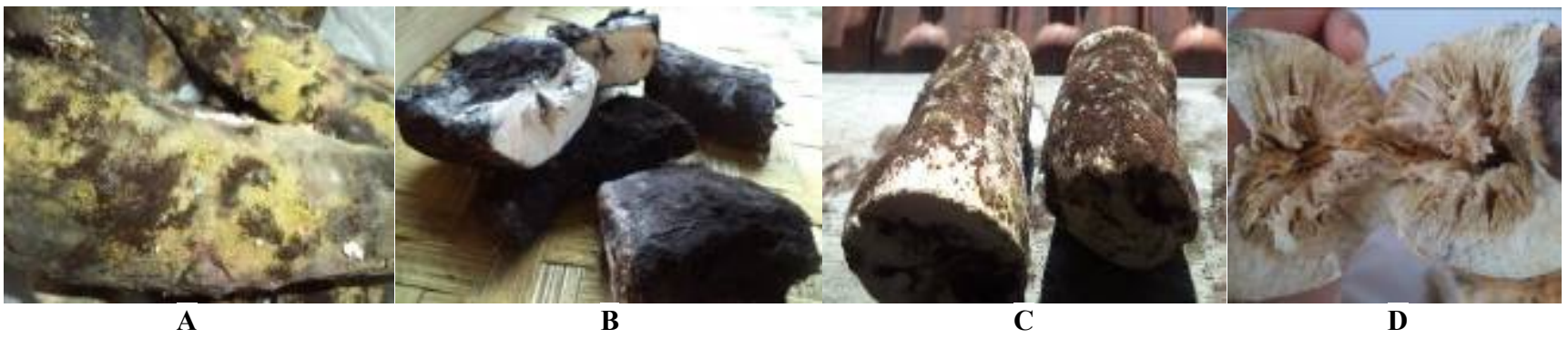

Figure 2. Dominant unwanted microbial strain on the cassava tuber, i.e., Trichoderma sp. (A), Aspergillus niger (B and C), rotten cassava caused by yeast during solid state fermentation (D)

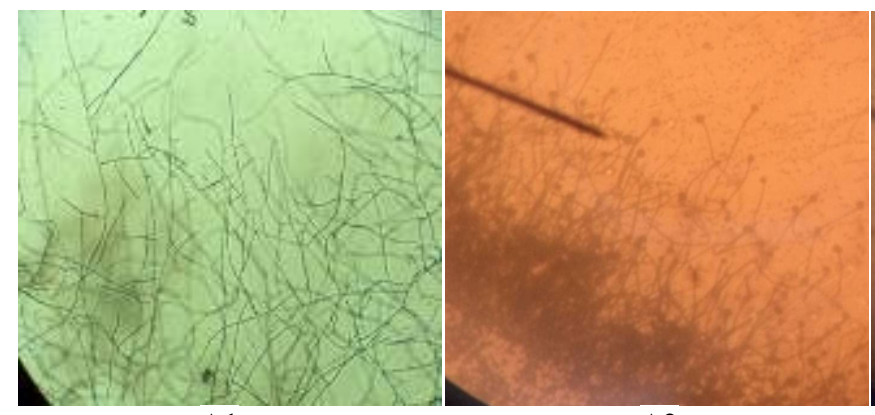

A2

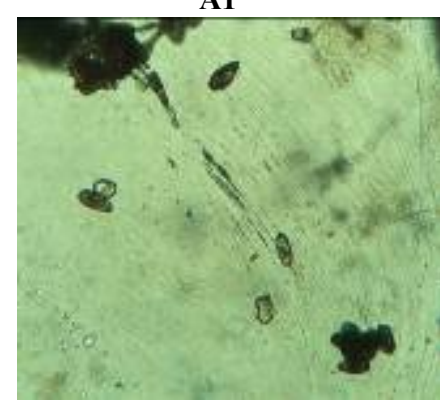

B1

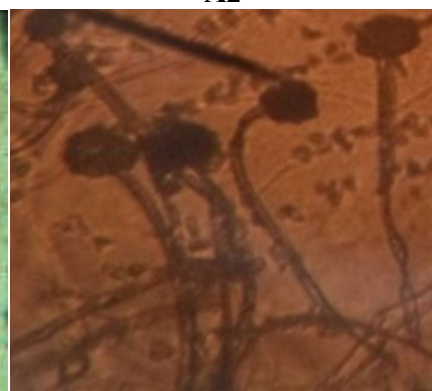

B2

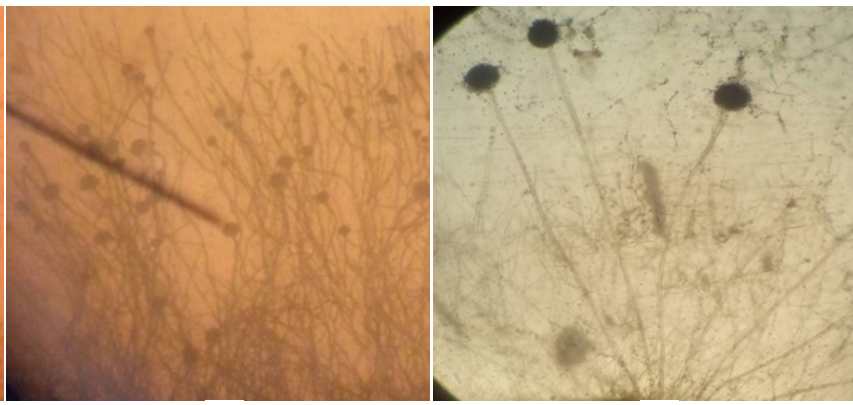

A3

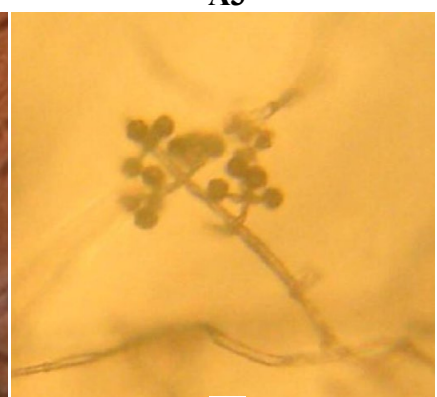

B3

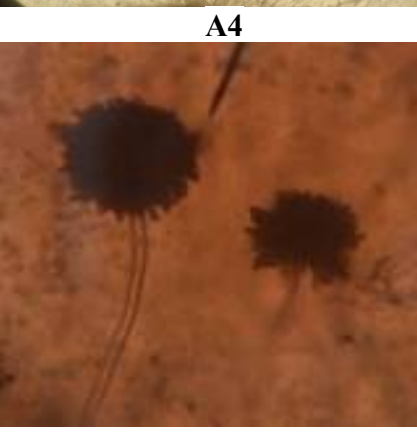

B4

Figure 4. Morphological characterization of the four dominant fungi under microscopic observation at 100x (A) and 400x (B) magnification

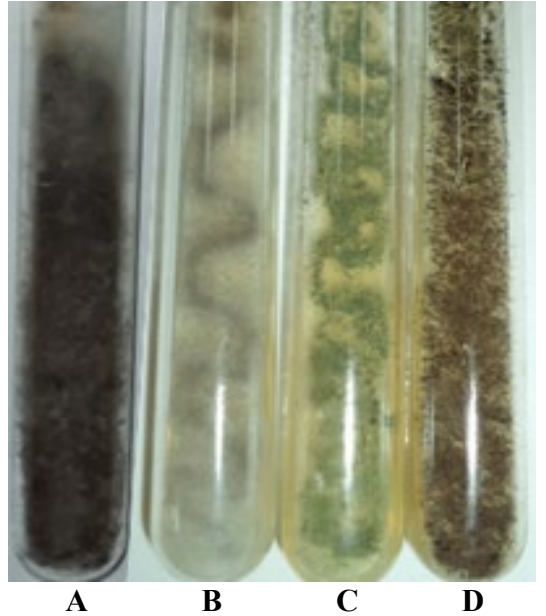

Figure 3. Isolates of the indigenous dominant fungi from "gatotan"
Fungus isolate no. (1) had very fine and greyish white of mycelia color on MEA plate which subsequently turned black when it mature based on the macroscopic observation. During incubation, the pycnidia were found (Figure 4.A1). The pycnidia were a round or bottle fruit body form that containing conidia. Based on the microscopic observation, this fungi had septate hyphae. When the pycnidia were open, the conidia (spore) would be spread. The conidia were observed using microscope at $400 \mathrm{x}$ magnification (Figure 4.B1). This fungus was identified as B. theobromae, which had the same characteristic as reported by Yan et al. (2013). Purwandari (2000) also observed the presence of $B$. theobromae in the 'gatotan'. The hyphae were penetrated to the cassava tuber and made tuber's appearance become greyish in the inside and outside of cassava tuber.

White mycelium or hyphae were observed in the second isolate (fungus no. 2). The sporangium color was grey and turn into black when it was mature. Based on the 
microscopic observation (Figure 4.A2 and 4.B2), the fungus had mycelium and sporangiophore that grew and elongated in the air either single or in groups. The hyphae penetrated to the substrate because of turgor pressure from the tip of mycelium. It called as rhizoid. The hyphae also grew on surface of the substrate and formed branching hyphae. The hypha produced globose sporangium when it matured. Based on these characteristics, the fungus was identified as $R$. oligosporus (Diaz et al. 2010; Yudiarti and Sugiharto 2016). R. oligosporus had rhizoid or vegetative hyphae that penetrated and hydrolized organic compound of the substrate. According to Gunter (2005), $R$. oligosporus produced amylase enzyme on a starchy substrate. $R$. oligosporus is common to appear in the traditional Indonesian food such as tempeh.

Fungus isolate no. (3) had green color of the mycelia, conidiophore, and colony. Based on the microscopic observation, this fungus had conidiophore as a sporangium (Figure 4.A3). The conidiophore looked like globose caused of some clustered conidia on the tip of phialides. In another side, each conidiophore produced lateral side branches phialides then the phialides produced some conidia. The conidiophore consisted of some rounded clusters of the conidia that attached to the phialides under the microscopic observation at 400x magnification (Figure 4.B3). Furthermore, the hyphae did not grow as high as other hyphae. The hyphae produced smaller branches and formed ultimately a conifer-like branching system. The conidiophores had primary branching arising from the main axis of mycelium. Kumar et al. (2012) reported that these characteristics of ts fungus were identified as Trichoderma sp. This fungus has branched hyphae which were growing to the top and the side. Trichoderma sp. is cellulolytic dan amylolytic fungus. It is commonly found in the organic material such as leaf and carbohydrate raw-material waste (Kusnadi et al. 2008).

Fungus isolate no. (4) had a yellow color of the mycelia, black color and globose of the conidiophore. The size of conidiophore was larger than the sporangium of $R$. oligosporus based on the macroscopic observation (Figure 4.A4). The conidiophore formed by some conidia and phialides that clustered and looked compact like globose sporangium. Same as Trichoderma sp., this fungus had conidiophore that consisted of the phialides and conidia, but the phialides and conidia of this fungus had a different structure of Trichoderma sp. This fungus had chains of conidia on the tip of phialides, meanwhile Trichoderma sp. had rounded clusters conidia on the tip of phialides. The clustered phialides were forming into large globose (Figure 4.B4). The fungus didn't have branching hyphae. The hyphae were growing to extend upward (Figure 4.A4). The morphological characteristics of this fungus corresponded with $A$. niger which has been identified by other researchers (Anderson and Smith 1971; Jorgensen et al. 2011). A. niger had black and globose sporangium. This fungus produced ochratoxin A (OTA) after seven days incubation (Senaye et al. 2015). The OTA toxicity limit of the contaminated food for human consumption is 0.2 to 1.6 $\mu \mathrm{g} \mathrm{OA} / \mathrm{kg}$ (Riemann and Cliver 2006).
The four indigenous fungi were identified as $B$. theobromae, Trichoderma sp., R. oligosporus and A. niger. The dominant fungi isolated from the 'gatot' fermentation in this study were different with the fungi on the 'gatot' fermentation in the previous studies (Buddhiati et al. 1995; Yudiarti and Sugiharto 2016; Purwandari 2000). Different location of the 'gatot' production was proposed as the reason. Every region has specific dominant microflora diversity which grows during spontaneous fermentation. Each fungus produced different compounds as a secondary metabolite. Trichoderma sp. and A. niger produced toxin as a secondary metabolite. $R$. oryzae was reported had phenolic compounds of $16.08 \pm 0.16 \mathrm{mg} / 100 \mathrm{~g}$. While Acremonium charticola produced phenolic compound about $26.25 \pm 0.39 \mathrm{mg} / 100 \mathrm{~g}$ (Sugiharto et al. 2016). Differences in the amount of secondary metabolite produced by the fungi might give different flavor of the 'gatotan' as a product from fungi activities.

\section{The dominant indigenous $\mathrm{LAB}$ during 'submerged fermentation of 'gatot' and its morphological- physiological characteristics}

Six lactic acid bacteria (LAB) isolated from the submerged fermentation of the 'gatot' were analyzed based on the largest area of the clear zone on the MRSA $+\mathrm{CaCO}_{3}$ medium. The isolates were tested on gram staining and coded as A1, A2, B1, B2, C1 and C2 (Figure 5). All of the indigenous LAB isolates had white-round or oval colony, convex elevation, gram-positive bacteria, a rod-shape (bacilli) cell under microscopic observation at 1000x magnification (Figure 5). Putri et al. (2012) reported that the characteristic of the lactic acid bacteria was coccus or bacilli shape and positive gram bacteria. Morphological and physiological characteristics of the LAB from submerged fermentation of 'gatot' were presented in Table 1.

The indigenous LAB grew well in MRSB medium, only at $37^{\circ} \mathrm{C}$ either in 24 hours or 48 hours (Table 1). The growth performance of $\mathrm{LAB}$ was not detected at $10^{\circ} \mathrm{C}$ and $50^{\circ} \mathrm{C}$. It showed that $\mathrm{LAB}$ was mesophilic bacteria. The optimum growth temperature of LAB was also observed by Nurhayati et al. (2011) in the spontaneous fermentation of banana. This indigenous LAB grew at $35-37^{\circ} \mathrm{C}$. Manini et al. (2016) also reported that LAB isolated from wheat bran sourdough had the growth rate temperature at $30-37^{\circ} \mathrm{C}$. Lactobacillus sp. could grow during 24-48 hours incubation (Ammor et al. 2005). Catalase enzyme test for the LAB isolates showed that all of the isolates did not produce bubbles after dropped of $\mathrm{H}_{2} \mathrm{O}_{2}$ solution. It indicates that LAB didn't produce catalase enzyme (negative catalase). Therefore, the LAB isolates couldn't hydrolyze the $\mathrm{H}_{2} \mathrm{O}_{2}$ into $\mathrm{O}_{2}$ and $\mathrm{H}_{2} \mathrm{O}$. Putri et al. (2012) reported that LAB was anaerobic facultative and did not produce catalase enzyme.

Five of the indigenous LAB isolates could be identified as the species of bacteria, but one isolate (the $\mathrm{B} 2$ isolate) was unidentified based on the BBL crystal kit test. Generally, all of the LAB isolates were able to ferment phenylalanine, arginine, and isoleucine. The LAB isolates had different ability in fermenting the specific substrates (Table 2). The different of profile fermentation determined 
the LAB species. Beside ferment the general substrates, the A1 isolate also can ferment the other substrates such as valine, glucose, pyroglutamic acid, tryptophan, trehalose, lactose, methyl-glucoside, sucrose, mannitol, maltotriose, arabinose, fructose, proline, galactose, and identified as Lactobacillus manihotivorans with the similarity percentage of $98.87 \%$. Furthermore, the A2 isolate was identified as Bacillus licheniformis $(87.32 \%$ of similarity percentage), the B1 isolate was identified as Brevibacillus brevis $(99.91 \%$ of similarity percentage) and the $\mathrm{C} 1$ isolate was identified as Lactobacillus fermentum with the similarity percentage of $42.71 \%$. The $\mathrm{C} 2$ isolate was identified as the same bacteria as the A1 isolate, i.e. $L$. manihotivorans, because they fermented the same carbon sources on BBL crystal kit plate test. However, the $\mathrm{C} 2$ isolates had a lower similarity species identification percentage $(55.12 \%)$ than that of the A1 isolate $(90.87 \%)$. A high percentage of similarity indicates the proximity of species estimation between isolated bacteria with reference bacteria in the BBL database based on their ability to ferment the various substrate.

Table 1. Morphological and physiological characteristic of lactic acid bacteria isolated from 'gatot' during submerged fermentation

\begin{tabular}{|c|c|c|c|c|c|c|c|c|c|c|}
\hline \multirow{4}{*}{$\begin{array}{l}\text { Code of } \\
\text { isolates }\end{array}$} & \multicolumn{3}{|c|}{ Morphological characteristic } & \multicolumn{7}{|c|}{ Physiological characteristic $\square$} \\
\hline & \multirow{3}{*}{ Typical of colony } & \multirow{3}{*}{$\begin{array}{c}\text { Gram } \\
\text { staining }\end{array}$} & \multirow{3}{*}{ Cell form } & \multicolumn{6}{|c|}{ Growth temperature $\left({ }^{\circ} \mathrm{C}\right)$} & \multirow{3}{*}{$\begin{array}{c}\text { Catalase } \\
\text { activity } \\
\text { test }\end{array}$} \\
\hline & & & & & 24 hou & & & hours & & \\
\hline & & & & $10^{\circ} \mathrm{C}$ & $37^{\circ} \mathrm{C}$ & $50^{\circ} \mathrm{C}$ & $10^{\circ} \mathrm{C}$ & $37^{\circ} \mathrm{C}$ & $50^{\circ} \mathrm{C}$ & \\
\hline A1 & White-round, convex elevation & Positive & Rod shape & - & + & - & - & ++ & - & - \\
\hline A2 & White-oval, convex elevation & Positive & Rod shape & - & + & - & - & ++ & - & - \\
\hline B1 & White-oval, convex elevation & Positive & Rod shape & - & + & - & - & ++ & - & - \\
\hline B2 & White-round, convex elevation & Positive & Rod shape & - & + & - & - & ++ & - & - \\
\hline $\mathrm{C} 1$ & White-round, convex elevation & Positive & Rod shape & - & + & - & - & ++ & - & - \\
\hline $\mathrm{C} 2$ & White-round, convex elevation & Positive & Rod shape & - & + & - & - & ++ & - & - \\
\hline
\end{tabular}

Note: $\mathrm{A} 1, \mathrm{~A} 2=\mathrm{LAB}$ isolates at the 24 hours fermentation, $\mathrm{B} 1, \mathrm{~B} 2=\mathrm{LAB}$ isolates at the 48 hours fermentation, $\mathrm{C} 1, \mathrm{C} 2=\mathrm{LAB}$ isolates at the 72 hours fermentation, $(+)=$ There was growth of $\mathrm{LAB},(-)=$ There was no growth of $\mathrm{LAB}$, or no catalase enzyme production

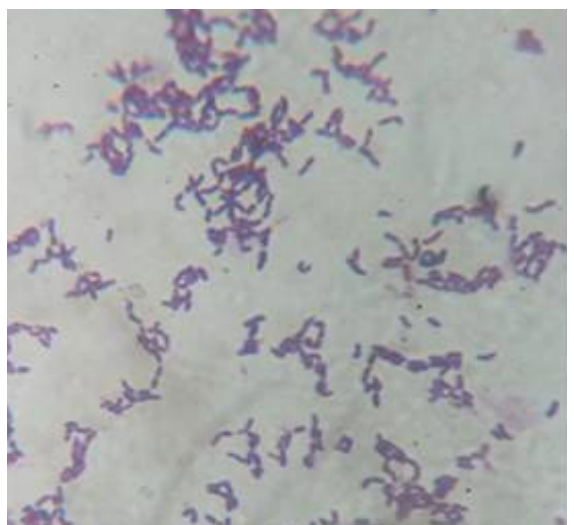

A1

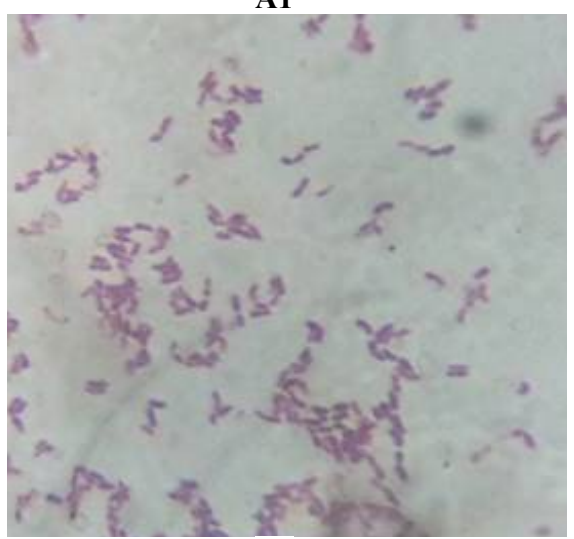

A2

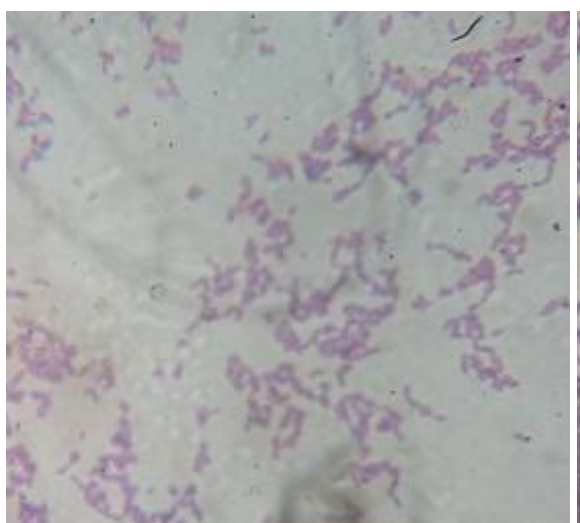

B1

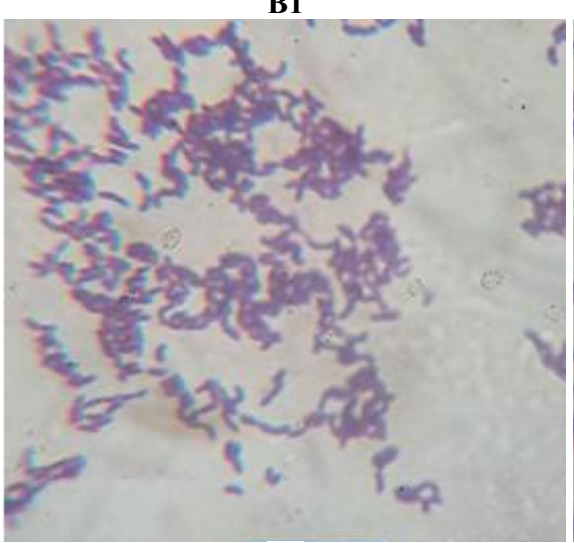

B2

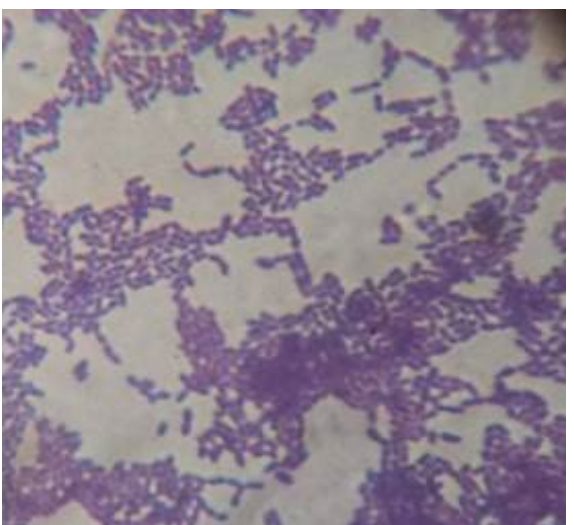

C1

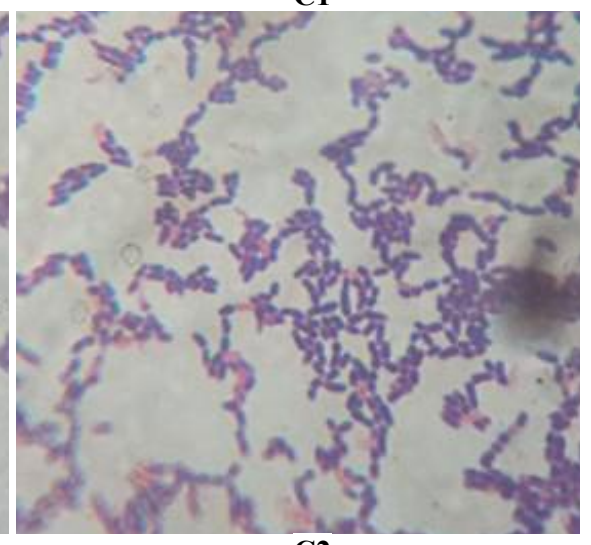

C2

Figure 5. The bluish purple color from gram staining and cell form of two selected colony of LAB isolates under microscopic observation at 1000x magnification on different fermentation time 24 hours (A); 48 hours (B); 72 hours (C) 
Table 2. Fermentation profile of LAB isolates using BBL Crystal kit test

\begin{tabular}{|c|c|c|c|c|c|c|c|c|c|c|c|c|c|c|c|c|c|c|c|c|c|c|c|c|c|c|c|}
\hline $\begin{array}{l}\text { Code } \\
\text { of } \\
\text { isolates }\end{array}$ & $\bigcup_{1}$ & $\sum_{i}^{\pi}$ & $\frac{\pi}{2}$ & $\bigcup_{1}^{\infty}$ & $\vec{x}$ & $\underset{x}{a}$ & $\underset{I}{\underline{I}}$ & 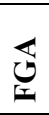 & $\stackrel{0}{\underline{x}}$ & $\underline{\Omega}$ & 寊 & $\underset{\lrcorner}{\longleftarrow}$ & $\sum$ & $\stackrel{\cup}{\mathscr{U}}$ & $\underline{E}$ & $\sum$ & 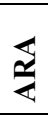 & $\underset{a}{a}$ & $\underset{\oplus}{0}$ & $\underset{\Omega}{0}$ & $\frac{Z}{2}$ & $\stackrel{0}{\stackrel{0}{a}}$ & $\sum_{a}$ & $\begin{array}{l}0 \\
\vdots \\
0\end{array}$ & $\underset{\widetilde{u}}{\longleftarrow}$ & $\begin{array}{c}\text { Identified } \\
\text { species of } \\
\text { bacteria }\end{array}$ & $\begin{array}{c}\text { \% Identification } \\
\text { based on BBL } \\
\text { crystal kit test }\end{array}$ \\
\hline A1 & - & + & ++ & ++ & ++ & ++ & ++ & - & - & ++ & + & + & + & + & + & + & + & + & - & - & + & - & - & + & ++ & L. manihotivorans & 90.87 \\
\hline $\mathrm{A} 2$ & - & - & ++ & - & ++ & ++ & - & ++ & ++ & ++ & + & + & + & + & + & + & + & + & - & - & + & + & - & - & ++ & B. licheniformis & 87.32 \\
\hline B1 & ++ & - & ++ & - & ++ & ++ & - & ++ & ++ & ++ & - & - & - & + & - & - & - & + & + & + & + & + & + & + & + & B. brevis & 99.91 \\
\hline B2 & - & - & ++ & + & ++ & ++ & + & ++ & - & ++ & + & + & + & - & - & - & + & + & - & - & + & - & + & + & ++ & No identification & - \\
\hline $\mathrm{C} 1$ & - & + & ++ & + & - & ++ & ++ & + & - & ++ & + & + & + & + & + & + & + & - & - & - & + & - & - & - & ++ & L. fermentum & 42.71 \\
\hline $\mathrm{C} 2$ & - & + & ++ & ++ & ++ & ++ & ++ & + & - & ++- & + & + & + & + & + & + & + & + & - & - & + & - & - & + & ++ & L. manihotivorans & 55.12 \\
\hline
\end{tabular}

Note: FGC (glucose), FVA (valin), FPH (phenylalanine), FGS (glucose), FPY (pyroglutamic acid), FAR (arginine), FTR (tryptophan), FGA (glucosamide), FHO (phosphat), FIS (isoleucine), TRE (trehalosa), LAC (lactose), MAB (metyl-glucoside), SUC (sucrose), MNT (manitol), MTT (maltotriose), ARA (arabinose), FRU (fructose), BGL (glucoside), PCE (cellobiose), PLN (proline), PHO (phosphat), PAM (maltoside), PGO (galaktoside), ARG (arginine)

In another study, Lactobacillus plantarum-pentosus, $L$. plantarum, L. fermentum and Pediococcus sp. were found on 'gatot' fermentation at Yogyakarta, Central Java (Rahayu 2003). Nuraida (2015) reported that L. plantarum Mut 7 and Mut 13 isolated from 'gatot' had promising characteristics as a probiotic candidate. The different area might result in different species of dominant LAB. In a study conducted by Guyot et al. (2000), the $L$. manihotivorans was found during sour cassava starch fermentation. L. manihotivorans was reported as homofermentative LAB that produced L- $(+)$ lactic acid and the $\alpha$-amylase enzyme. L. fermentum was identified on some fermented food from Nigeria (Sanni et al. 2002). Furthermore, amylolytic lactic acid bacteria (L. plantarum and L. rhamnosus) were found during fermentation of 'growol' (an Indonesian fermented food) (Putri et al. 2012). Manini et al. (2016) isolated several LAB from wheat bran sourdough, i.e. Leuconostoc mesenteroides, Leuconostoc citreum, Lactobacillus brevis, Lactobacillus sakei, and Pediococcus pentasaceus, which were able to ferment Dglucose, D-fructose, D-maltose and $\mathrm{N}$-acetylglucosamine based on the API $50 \mathrm{CH}$ system.

In conclusion, there were four dominant indigenous fungi and four dominant indigenous LAB isolated from 'gatot' fermentation in Trenggalek District, East Java, Indonesia. The fungi were $B$. theobromae, $R$. oligosporus, Trichoderma sp. dan $A$. niger. The indigenous LAB was identified as L. manihotivorans, B. licheniformis, B. brevis, and L. fermentum. B. theobromae and $R$. oligosporus were desired fungi, while Trichoderma sp. dan A. niger were unwanted fungi during solid-state fermentation of the 'gatotan'. L. manihotivorans and L. fermentum were potential LAB among the other. In the future research, the selected fungi and LAB isolates from 'gatot' fermentation can be used as starter cultures for controlled fermentation of the 'gatot' production.

\section{ACKNOWLEDGEMENTS}

This research was funded by Indofood Riset Nugraha (IRN) 2013/2014 No. SKE.055/S1/IRN-ISM/VI/2013 from PT Indofood Sukses Makmur Tbk. Indonesia and Stranas
Research Program 2016/2017 No. 042.06-0/2016 from Ministry of Research, Technology and Higher Education, Republic of Indonesia.

\section{REFERENCES}

Ammor S, Rachman C, Chaillou S, Prevost H, Dousset X. 2005. Phenotypic and genotypic identification of lactic acid bacteria isolated from a small-scale facility producing traditional dry sausages. J Food Microbiol Aust 22: 373-382.

Anderson JG, and Smith JE. 1971. The Production of conidiophores and conidia by newly germinated conidia of Aspergillus niger (microcycle conidiation). J Microbiol 69: 185-197.

Becton, D. 2010. Manual of BD BBL Crystal Identification Systems: Gram-positive ID Kit. Becton, Dickinson and Company, USA.

Budhiatti TH, Asmara W, Budiarso TY. 1995. Production of AlfaAmylase Enzyme by Rhizopus oligosporus, Aspergillus niger and Mucor griseocyanus from Cassava Starch Substrate (Cassava sp.). Universitas Kristen Duta Wacana, Yogyakarta. [Indonesian]

Burns AE, Bradbury JH, Cavagnaro TR, Gleadow RM. 2012. Total cyanide content of cassava food products in Australia. J Food Compos Anal 25: 79-82.

Chikezie PC, Ojiako OA. 2013. Cyanide and aflatoxin loads of processed cassava (Manihot esculenta) tubers (Garri) in Njaba, Imo State, Nigeria. Toxicol Intl 20 (3): 261-267.

Diaz BHC, Aparicio AJ, Perez JJC, Dominguez GC, Beltran LA, Sanchez HH, Lopez GFG. 2010. Morphological characterization of the growing front of Rhizopus oligosporus in solid media. J Food Eng 101: $309-317$

FAO/WHO. 2003. Codex Standard for Sweet Cassava. Codex Standard 238-2003. Food and Agriculture Organization and World Health Organization of the United Nations, Rome.

Guyot J, Calderon M, Morlon-Guyot J. 2000. Effect of $\mathrm{pH}$ control on lactic acid fermentation of starch by Lactobacillus manihotivorans LMG $18010^{\mathrm{T}}$. J Appl Microbiol 88: 176-182.

Jorgensen TR, Park J, Arentdhorst M, van Welzen AM, Lamers G, vanKuyk PA, Damveld RA, van den Hondel CAM, Nielsen KF, Frisvad JC, Ram AFJ. 2011. The molecular and genetic basic of conidial pigmentation in Aspergillus niger. J Fungal Genet Biol 48 (5): 544-553

Kumar K, Amaresan N, Bhagat S, Madhur K, Srivastava RC. 2012. Isolation and characterization of Trichoderma spp. for antagonistic activity against root rot and foliar pathogens. Indian J Microbiol 52 (2): 137-144.

Kusnadi, Saefudin, Efrianti A. 2008. Diversity of cellulolytic and amylolytic fungi that decompose organic waste from several substrates. Universitas Diponegoro, Semarang. [Indonesian]

Manini F, Casiraghi MC, Poutanen K, Brasca M, Erba D, Plummed-Ferrer C. 2015. Characterization of lactic acid Bacteria isolated from wheat bran sourdough. LWT Food Sci Technol 66: 275-283. $\square$ 
Nuraida L. 2015. A review: Health promoting lactic acid bacteria in traditional Indonesian fermented foods. Food Sci Human Wellness 4 47-55.

Nurhayati E, Mulyana, Ekowati VI, Meilawati A. 2014. Inventories Javanese traditional offering food in Bantul traditional market. Jurnal Penelitian Humaniora 19 (2): 124-140. [Indonesian]

Nurhayati N, Jenie BSL, Kusumaningrum HD, Widowati S. 2011. Phenotypic and genotypic identification of lactic acid bacteria during spontaneous fermentation of unripe var agung semeru banana (Musa paradisiaca Formatypica). J Ilmu Dasar 12: 114-225. [Indonesian]

Olympia M, Fukuda H, Ono H, Kaneko Y, Takano Y. 1995. Characterization of starch-hydrolyzing lactic acid bacteria isolated from a fermented fish and rice food, 'Burong Isda,' and its amylolytic enzyme. J Ferment Bioeng 80: 124-130.

Padmaja G, Steinkraus KH. 2009. Cyanide detoxification in cassava for food and feed uses. Crit Rev Food Sci Nutr 35: 299-339.

Purwandari U. 2000. Chapter V. Fungal Distribution in Gathotan Samples. [Thesis]. Royal Melbourne Institute of Technology University, Australia.

Purwandari U, Tristiana GR, Hidayati D. 2014. Gluten-free noodle made from gatotan flour: Antioxidant activity and effect of consumption on blood glucose level. Intl Food Res J 21 (5): 1629-1634.

Putri WDR, Haryadi DW, Marseno, Cahyanto MN. 2012. Isolation and characterization of amylolytic lactic acid bacteria during growo fermentation, an Indonesian traditional food. J Teknologi Pertanian 13: 52-60. [Indonesian]

Rahayu ES. 2003. Lactic acid bacteria in fermented foods of Indonesian origin. Agritech 23 (2): 75-84.
Reddy G, Altaf Md, Naveena BJ, Venkateshwar M, Kumar EV. 2008. Amylolytic bacterial lactic acid fermentation-A review. J Biotechnol Adv 26: 22-34.

Riemann PR, Cliver DO. 2006. Foodborne Infections and Intoxications. Elsevier, Amsterdam.

Sanni AI, Morlon-Guyot J, Guyot JP. 2002. New efficient amylaseproducing strains of Lactobacillus plantarum and L. fermentum isolated from different Nigerian traditional fermented foods. Intl $\mathrm{J}$ Food Microbiol 72: 53-62.

Senaye BK, Yu J, Williams L. 2015. Morphological and molecular characterization of ochratoxin A producing black Aspergilli from grape pomace. J Food Res 4 (5): 39-50.

Sugiharto S, Yudiarti T, Isroli I. 2016. Assay of antioxidant potential of two filamentous fungi isolated from the Indonesian fermented dried cassava. Antioxidants 5: 1-6.

Yan JY, Xie Y, Zhang W, Wang Y, Liu JK, Hyde KD, Seem RC, Zhang GZ, Wang ZY, Yao SW, Bai XJ, Dissanayake AJ, Peng YL, Li XH. 2013. Species of Botryosphaeriaceae involved in grapevine dieback in China. Fungal Divers 61: 221-236.

Yudiarti T, Sugiharto S. 2016. A novel filamentous fungus Acremonium charticola isolated from gathot (an Indonesian fermented dried cassava). Intl Food Res J 23: 1351-1354.

Zifcakova L, Vetrovaky T, Howe A, Baldrian P. 2016. Microbial activity in forest soil reflects the changes in ecosystem properties between summer and winter. J Environ Microbiol 19 (1): 288-301. $\square$

Zulkifli NA, Zakaria L. 2017. Morphological and molecular diversity of Aspergillus from corn grain used as livestock feed. Hayati J Biosci 24: 26-39. 